\title{
ПСИХОАОГИЧЕСКИЕ ИССАЕДОВАНИЯ
}

\section{PSYCHOLOGICAL STUDIES}

\author{
ФЕНОМЕН «ТЯНИ-ВЫТАЛКИВАЙ» \\ КАК ПРОЯВЛЕНИЕ ГЕНДЕРНОГО НЕРАВЕНСТВА \\ В ОРГАНИЗАЦИОННОМ КОНТЕКСТЕ
}

\author{
Гуриева С.Д. \\ Санкт-Петербургский государственный университет, \\ Санкт-Петербург, Российская Федерация
}

Сквозь призму гендерного подхода анализируются соииально-психологические явления, проявляющиеся в организации и отражающие ограничения для женщин в профессиональной сфере. Рассматриваются так называемые «стеклянные» феномены в организации: «стеклянный потолок» в профессиональной карьере женщин; "стеклянные стены» как вариант горизонтальной гендерной сегрегации; «стеклянный утес» - увеличение количества женщин на временных управленческих позищиях; «липкий пол»«застревание» на продолжительный период на начальных этапах построения карьеры. Предположение о причинах существования «стеклянных» феноменов и других проявлений гендерного неравенства в организачии объединены в две основные группы. Первая группа объясняет существование гендерного неравенства, исходя из сочиальных факторов «отягощения»- «Pull down»; вторая группа факторов - «риsh оиt», связана с организационными факторами, выталкивающим работающую женщину за предель компании. В настоящее время вопрос остаётся открытым: почему женщины «добровольно» уходят с рабочих мест и что современная организачия и общество могут предложить им взаимен. 
Ключевые слова: гендерное неравенство; «стеклянный потолок»; «стеклянный утес»; «стеклянные стены»; «липкий пол»; отягощение вниз; выталкивание.

\section{THE "PULL-PUSH" PHENOMENON AS A MANIFESTATION OF GENDER INEQUALITY IN THE ORGANIZATIONAL CONTEXT}

\section{Gurieva S.D.}

Saint Petersburg State University, Saint-Petersburg, Russian Federation

Through the prism of gender approach, socio-psychological phenomena that are manifested in the organization and reflect the limitations for women in the professional sphere are analyzed. We consider the so-called "glass" phenomena in the organization: "glass ceiling" in the professional career of women; "glass walls" as a variant of horizontal gender segregation; "glass cliff" - an increase in the number of women in temporary managerial positions;" sticky floor " - being for a long period at the initial stages of career building. Assumptions about the reasons for the existence of "glass" phenomena and other manifestations of gender inequality in the organization are grouped into two main groups. The first group explains the existence of gender inequality, based on social factors "Pull down"; the second group of factors - "push out", is associated with organizational factors that push a working woman out of the company. At present, the question remains: why women "voluntarily" leave their jobs and what modern organizations and society can offer them in return.

Keywords: gender inequality; "glass ceiling"; "glass cliff"; "glass walls"; "sticky floor"; pull-down, push out.

Гендерные ограничения в сфере труда имеют множество негативных последствий для женщин. Гендерное неравенство влияет на статус женщин в обществе. Следствием гендерного неравенства в 
организациях стало то, что женщинам доступен меньший диапазон профессий, предполагающих меньшую ответственность и/или меньшую оплату и меньшие возможности карьерного продвижения, таким образом, оказывается ограничен доступ женщин к экономическим ресурсам и к ресурсам власти. Все это делает актуальным исследование проблемы гендерного неравенства в организациях, описания социально-психологических феноменов и механизмов его воспроизводства.

\section{Проявления гендерного неравенства в организации}

Основное внимание исследований и средств массовой информации на протяжении длительного времени было сосредоточено на дискриминационной практике, сложившейся в организациях, барьеpax, с которыми сталкиваются женщины, продвигаясь по карьерной лестнице. К основным проявлениям гендерного неравенства в сфере труда можно отнести разницу в доходах мужчин и женщин и в уровне безработицы [Blau F.D., Kahn L.M., 2000, P. 75-99], меньшее количество женщин, занимающих высокие управляющие позиции, «двойные стандарты» в оценке женского и мужского труда, наличие социальных стереотипов о «женских» и «мужских» профессиях и ограничение возможностей женщин в нетрадиционных сферах деятельности. Так, например, к социально-психологическим феноменам, отражающим ограничения для женщин в профессиональной карьере, можно отнести «стеклянные» феномены. Для отражения опыта женщин в данной области, облегчения понимания данного социального явления и описания его проявления, используется метафора «стеклянный потолок». «Стекло» подчеркивает очевидность и частотность распространения данного феномена, прозрачность, тонкость и деликатность происходящего, ломкость и недолговечность занимаемой управленческой позиции. К числу «стеклянных» феноменов в карьере женщин относится не только «стеклянный потолок», установленный верхний предел в организации, выше которого женщина не может подняться; но и «стеклянные стены», вариант горизонтальной гендерной сегрегации; «стеклян- 
ный эскалатор», преимущество мужчин в «женских» профессиях»; «стеклянная скала», увеличение количества женщин на временных управленческих позициях. Кроме того, исследователями описан «липкий пол» - феномен, сходный по смыслу со «стеклянным потолком», но проявляющийся на нижнем уровне в карьерной иерархии, на начальных его ступенях.

Однако по мере того, как небольшое количество женщин начинает успешно пробиваться сквозь стекло, пробивать потолки и высвобождаться из «липких полов», основное внимание многих исследователей начинают привлекать женщины, решившие оставить карьеру. Основной акцент смещается с факторов дискриминации женщины в организации, на объяснение столь очевидного для работающей женщины явления - отказаться от работы и добровольно уйти. Женщина поставлена перед выбором, либо карьера, либо семья. Многие руководящие должности требуют высокого уровня приверженности, полной отдачи от работающей женщины. Поэтому, если женщина желает добраться до вершины карьерной лестницы, она должна изменить свои приоритеты, ценности, обязательно пожертвовать семейной жизнью, личным благополучием. Но есть женщины, которые предпочитают не жертвовать, не желают менять свои приоритеты в обмен на полный занятый рабочий день. Как выясняется, что женщины не желают более работать ради того, что они в результате не хотят получить [Belkin, 2003, Р. 47]; не желают брать на себя ответственность возглавлять руководящие позиции в науке и технике, требующие тотальной приверженности только работе [Summers, 2005]; примерно около половины женщин сознательно предпочитают не выходить на работу и не искать новую или просто не желают жертвовать собой ради работы, по причине того, что менее агрессивны и менее обеспокоены своим социальным статусом в отличии от мужчин [Williams, 2006]. Таким образом, мы подошли вплотную к проявлению в рамках современной организации и общества, группы двух факторов «Pull down» (тяни вниз) и «push out» (выталкивай). К семейным факторам, тянущим вниз, относятся следующие: семья, дети, пожилые члены семьи, 
образ жизни, полоролевые отношения. К организационным фактором, выталкивающим женщину за пределы организации, с рабочего места, являются сформировавшиеся аспекты организационной культуры, рабочей среды, сложившаяся система барьеров, заставляющие женщины сделать выбор [Hewlett and Luce, 2005]. Более того, в одном из бизнес-исследований было доказано, что именно заставляет женщин покинуть рабочие места. Отсутствие смысла в работе, востребованности, удовлетворенности, возможностей для развития и прогресса значительно перевесило желание быть дома со своими детьми, семьей. Почему женщины покидают работу, уходят с управленческих позиций? Вопрос остается открытым для дальнейших исследований.

Работа публикуется при финансовой поддержке РФФИ, проект № 19-013-00686-A.

\section{Лumepamypa / References}

1. Blau F.D., Kahn L.M. Gender Differences in Pay // Journal of Economic Perspectives. 2000. Vol. 14, №4, pp. 75-99.

2. Belkin L.Q: Why don't more women choose to get to the top? A: They choose not to // New York Times Magazine, 2003. 58, p. 42-47.

3. Summers L.H. Remarks at NBER Conference on Diversifying the Science \& Engineering Workforce, January 14, 2005. Cambridge, MA.

4. Williams J.C. Opt Out or Pushed Out? How the Press Cover Work // Family Conflict. The Center for Work Life Law, 2006. University of California, Hastings College of Law, CA.

5. Hewlett S.A., \& Luce C.B. Off-ramps and on-ramps: Keeping talented women on the road to success. Harvard Business Review, March, 2005.1-10. 